\title{
Ewa GORLEWSKA
}

Uniwersytet w Białymstoku ewa.gorlewska@wp.pl

\section{SLOWNICTWO AKSJOLOGICZNE W KONSTYTUCJI RZECZYPOSPOLITEJ POLSKIEJ - WYBÓR I KLASYFIKACJA}

\section{WPROWADZENIE}

Celem artykułu jest zaprezentowanie pojęć aksjologicznych zawartych we współczesnej polskiej Konstytucji i wskazanie wybranych problemów związanych z ich uporządkowaniem. Rozważania dotyczą głównie kryteriów wyboru katalogu pojęć oraz metod klasyfikacji pozyskanej leksyki, w mniejszym stopniu zaś źródła materiału badawczego. Zwrócę uwagę na trudności metodologiczne związane $\mathrm{z}$ wyborem i usystematyzowaniem słownictwa aksjologicznego zawartego w Konstytucji, a także przedstawię i uzasadnię podjęte przeze mnie decyzje badawcze dotyczące formułowania listy nazw wartości oraz ich typologii.

Niniejszy tekst jest wstępnym rezultatem pracy badawczej ${ }^{1}$ poświęconej sposobom rozumienia nazw wartości ujętych w Konstytucji. Wybór i klasyfikacja nazw wartości jest pierwszym krokiem w kierunku rekonstrukcji językowego obrazu wartości wyznawanych w czasie przemian politycznych schyłku lat 80 . XX wieku oraz katalogu wartości cenionych współcześnie ${ }^{2}$. W tym artykule często posługuję się terminami „poję-

1 Artykuł ten prezentuje wstępny ogląd problematyki, której poświęcę rozprawę doktorską przygotowywaną w Instytucie Filologii Polskiej Uniwersytetu w Białymstoku pod kierunkiem dr hab. Ireny Szczepankowskiej.

$2 \mathrm{~W}$ badaniu semantyki nazw wartości konstytucyjnych i sposobu rozumienia kategorii aksjologicznych przez respondentów posłuży mi zasada S - A - T sformułowana przez Jerzego Bartmińskiego. Ten typ analizy polega na zestawieniu trzech rodzajów źródeł: systemu (S), ankiet (A) i tekstu (T) oraz ich synchronicznej interpretacji (Bart- 
cie” i „nazwa”. W pewnych ujęciach denotacja tych terminów okazuje się zbieżna, co nie sprzyja ich precyzyjnemu użyciu. W pracach językoznawczych słowo "pojęcie” jest używane jako bliskoznacznik takich określeń, jak: „znaczenie”, , termin”, ,kategoria językowa”, ,"nazwa” oraz "sposób rozumienia nazwy", choć $w \dot{z} a d n y m z$ tych użyć nie jest to słowo jednoznaczne (Szczepankowska 2007: 170). Aby uniknąć wieloznaczności terminologicznej, przyjmę następującą interpretację „pojęcia”: 'Fragment ludzkiej wiedzy o świecie, umysłowy obraz wyodrębnionych językowo kategorii obiektów' (por. Szczepankowska 2011: 110). W tym ujęciu określenie to odsyła do sposobu rozumienia nazw przez użytkowników języka. Łączy obiektywne cechy nazywanych obiektów z podmiotowym wyobrażeniem o nich (interpretacją dokonaną w umyśle mówiącego). Pod terminem „nazwa” rozumiem natomiast 'wyraz, który wskazuje (desygnuje) jakiś element rzeczywistości pozajęzykowej' (por. Szczepankowska 2011: 106; SJP PWN 2006: 495).

\section{KONSTYTUCJA RZECZYPOSPOLITEJ POLSKIEJ JAKO ŹRÓDŁO SŁOWNICTWA AKSJOLOGICZNEGO}

Ustawa zasadnicza obowiązująca obecnie w Polsce zawiera zestaw wartości uznanych za istotne w czasie przemian ustrojowych końca lat 80. XX wieku. Manifestuje się w niej taki system pojęć aksjologicznych, który odzwierciedla sposób oceniania rzeczywistości przez osoby żyjące w tamtym okresie. Ustawa zasadnicza jest tekstem, który w dużym stopniu przybliża wyobrażenia i opinie wspólnotowe (Bartmiński 2014: 314). Jednocześnie wspólnotowość ta nie może mieć u podstaw nakazu wyznawania określonych wartości. Konstytucja jest dokumentem ważnym dla rekonstrukcji językowego obrazu wartości cenionych przez społeczeństwo,

miński 2014: 312). W prowadzonych przeze mnie badaniach wezmę pod uwagę następujące źródła: aktualną Konstytucję Rzeczypospolitej Polskiej - tekst; słowniki języka polskiego i specjalistyczne (etyczne i prawnicze) - system oraz wypowiedzi respondentów - ankieta. Treść ustawy zasadniczej pozwoli na zrekonstruowanie katalogu wartości relewantnych z perspektywy wspólnoty narodowej reprezentowanej przez starsze pokolenie. Opisy semantyczne nazw wartości dostarczą wiedzy o tym, jakie znaczenia nazw wartości ugruntowały się w języku polskim. Wypowiedzi ankietowe przyniosą natomiast odpowiedź na pytanie, jakie rozumienie poszczególnych wartości dominuje w języku młodych ludzi. 
ponieważ stanowi depozyt który odzwierciedla i chroni wartości, ideały, symbole podzielane przez społeczność (Weiler 2003: 30). Dzięki temu, poprzez analizę lingwistyczną nazw wartości, możliwe jest dotarcie do aksjologii dominującej wśród przedstawicieli danego pokolenia. Wartości konstytucyjne ujęte są w pewne pojęcia mające odsyłać odbiorców dokumentu do określonej rzeczywistości pozajęzykowej, z założenia pojmowanej przez nich $\mathrm{w}$ podobny sposób. To, jak te wartości są rozumiane, zmienia się jednak wraz z przekształcaniem się sposobu myślenia użytkowników języka. Rozwój i dojrzewanie społeczeństwa skutkuje dokonującym się w nim tak zwanym „przewartościowaniem wartości”3, czyli modyfikacją znaczeń ustalonych za pomocą definicji i zmianą sposobu rozumienia nazw wartości. Jerzy Bartmiński zwrócił uwagę, że po przełomie 1989 roku pojawiło się kilka dyskursów publicznych różnych co do deklarowanych $i$ wyznawanych wartości (Bartmiński 2006: 8). Proces różnicowania się postaw moralnych we wspólnocie obywatelskiej obecnie wydaje się przybierać na sile. Publiczne głosy przypominające o ujętych w Konstytucji tradycyjnych wartościach i ich dość jednoznacznej interpretacji przeplatają się z wypowiedziami, w których podkreślana jest wolność jednostki w wymiarze osobistym i światopoglądowym (uwzględniająca wybór i nieskrępowane głoszenie wyznawanej aksjologii) - także sankcjonowana w ustawie zasadniczej. Przypadki nieporozumień na tym tle ujawniają wyraźną antynomię wartości prezentowanych w Konstytucji (Stawrowski 2007: 50). Zebranie i analiza materiału badawczego, jakim jest słownictwo aksjologiczne zawarte $\mathrm{w}$ Konstytucji, ma być pierwszym krokiem w kierunku rekonstrukcji obecnego sposobu rozumienia nazw wartości konstytucyjnych $\mathrm{w}$ porównaniu $\mathrm{z}$ ich pojmowaniem prezentowanym $\mathrm{w}$ czasie kształtowania się treści dokumentu.

Wyznawana aksjologia jest elementem warunkującym tożsamość wspólnoty (Bartmiński 2014: 10). Zbadanie sposobu rozumienia nazw wartości w różnych pokoleniach może ujawnić nie tylko różnice językowe związane z dawnych i obecnym profilowaniem pojęć aksjologicznych, lecz także odmienne światopoglądy głoszone w ramach jednego narodu.

3 Zjawisko przewartościowania wartości opisał Fryderyk Nietzsche (Nietzsche 1910: 3). Jest przez niego rozumiane jako utrata wartości przez dotychczas dodatnio oceniane stany rzeczy, a w konsekwencji potrzeba pojawienia się nowego katalogu wartości. 
3. SŁOWNICTWO AKSJOLOGICZNE W KONSTYTUCJI RZECZYPOSPOLITEJ POLSKIEJ - CHARAKTERYSTYKA OGÓLNA, KRYTERIA WYBORU POJĘĆ, LISTA HASEŁ

\section{A) CHARAKTERYSTYKA OGÓLNA SŁOWNICTWA AKSJOLOGICZNEGO}

Ustawa zasadnicza jest tekstem łączącym funkcję prawną (regulowanie porządku państwowego) i społeczną (spajanie wspólnoty obywateli). Wartości konstytucyjne nie są więc katalogiem obiektywnie pojmowanych kategorii aksjologicznych, lecz stanowią element państwowej (polityczno-społecznej) wizji świata. W ustawie zasadniczej wartościowane są przede wszystkim te aspekty rzeczywistości, które wiążą się z państwem jako pewną strukturą polityczną, ekonomiczną i socjalną. W Konstytucji wysoko oceniane są postawy wzmacniające wspólnotę obywatelską, duża część słownictwa skupiona jest zatem wokół zagadnień związanych ze społeczeństwem. Druga obszerna grupa nazw wartości dotyczy rzeczywistości państwowej: spraw związanych z ustrojem politycznym, prawem i gospodarką. Mniej miejsca poświęca się tu wartościom cenionym ze względu na osobiste, jednostkowe dobro człowieka. Typy słownictwa zebranego na podstawie treści Konstytucji są w dużej mierze zbieżne z kategoriami nazw wartości, które wyodrębnia Jerzy Bartmiński w projekcie listy haseł do słownika aksjologicznego (Bartmiński 1991: 202-203). Wybrane pojęcia dają się uporządkować wedle następujących grup: 1) nazwy abstrakcyjnych bytów pojmowanych jako wartości podstawowe, 2) nazwy dóbr przysługujących człowiekowi, 3) nazwy cnót osobowych, 4) nazwy postaw indywidualnych i zbiorowych, 5) nazwy zbiorowości ludzi, 6) nazwy sytuacji i stanów politycznych, 7) nazwy sytuacji i stanów społecznych, 8) nazwy obiektów będących nosicielami wartości, 9) nazwy obiektów będących symbolami wartości.

B) KRYTERIA WYBORU POJĘĆ

Jadwiga Puzynina wskazuje na funkcjonowanie w języku wyrazów prymarnie i wtórnie wartościujących (Puzynina 1992: 120). Pierwsze z nich zawierają definicyjny składnik wartościujący, co oznacza, że ocena jest wpisana $\mathrm{w}$ ich znaczenie denotacyjne. Drugie zaś mają konotacyjny składnik wartościujący - nie wskazują wartości wprost, lecz zawierają dodatkowy, skojarzeniowy element oceniający. 
Pojęcia aksjologiczne wybrane z aktualnej Konstytucji Rzeczypospolitej zostały wyodrębnione na podstawie dwu kryteriów: semantycznego i pragmatycznego. Oba kryteria stosowane łącznie pozwalają na uwzględnienie różnych wskazanych przez Puzyninę form przejawiania się wartościowania w leksyce. Kryterium semantyczne umożliwia zrekonstruowanie nazwy wartości na podstawie ich znaczeń (hiperonimem jest słowo wartość). Można dzięki temu dokonać ekscerpcji pojęć abstrakcyjnych mających składnik wartościujący w swojej definicji. Kryterium pragmatyczne zakłada z kolei udział użytkowników języka w procesie klasyfikowania leksemów oznaczających pewne stany rzeczy jako nazw wartości. Chodzi o wartościowanie obiektów, zdarzeń, zjawisk, faktów, które są dla danej społeczności szczególnie ważne. Dzięki zastosowaniu kryterium pragmatycznego możliwe jest wydobycie z tekstu Konstytucji nazw będących nośnikami wartości oraz symboli odsyłających do określonego wartościowania. W dokonaniu wyboru pojęć aksjologicznych pomogło mi także posłużenie się łączliwością składniowo-semantyczną nazw z pewnymi określeniami, na przykład: bronić, szanować, strzec, walczyć (o co), stać na straży, chronić, (być) pod ochronq, opiekować się, troszczyć się, zakazywać, przeciwdziałać. Obiekty, do których odnoszą się wymienione czynności, traktowałam jako elementy aksjologicznie nacechowane.

\section{C) LISTA HASEL}

Ostatecznie sformułowana lista haseł obejmuje 77 jednostek leksykalnych: 66 nazw wartości dodatnich i 11 nazw antywartości. Kontrwartości zostały przyporządkowane odpowiednim leksemom oznaczającym aksjologię dodatnią. Przyczyny tego nierównorzędnego traktowania obu grup nazw są wyjaśnione niżej (cz. 4, punkt A). Zaprezentowana lista nazw wartości konstytucyjnych jest spisem uporządkowanych alfabetycznie haseł. W nawiasach kwadratowych zostały ujęte określenia synonimiczne; w nawiasach okrągłych znalazły się nazwy antywartości.
1. Barwy Rzeczypospolitej Polskiej
6. Demokracja (faszyzm, komunizm, nazizm, totalitaryzm, przemoc)
2. Bezpieczeństwo
7. Dialog
3. Bóg
8. Dobre imię [cześć]
4. Chrześcijaństwo
9. Dobro
5. Człowiek
10. Dziecko 
11. Dziedzictwo narodowe

12. Godło Rzeczypospolitej Polskiej

13. Godność

14. Gospodarka

15. Humanitaryzm

16. Hymn Rzeczypospolitej Polskiej

17. Informacja

18. Język narodowy

19. Konstytucja

20. Kultura

21. Ludzkość

22. Macierzyństwo

23. Małżeństwo

24. Matka

25. Moralność

26. Naród

27. Nauka

28. Niepodległość

29. Obywatel

30. Odpowiedzialność

31. Ojczyzna

32. Państwo

33. Piękno

34. Pokój (wojna)

35. Polska [Rzeczpospolita]

36. Praca (bezrobocie)

37. Prawda
38. Prawo

39. Prywatność

40. Przodkowie

41. Religia

42. Rodacy

43. Rodzicielstwo

44. Rodzina

45. Równość (dyskryminacja)

46. Równouprawnienie

47. Solidarność

48. Społeczeństwo

49. Sprawiedliwość

50. Sumienie

51. Suwerenność

52. Szacunek (nienawiść)

53. Środowisko naturalne

54. Terytorium

55. Tożsamość

56. Tradycja

57. Walka

58. Własność

59. Wiara

60. Wolność [swoboda] (cenzura)

61. Wspólnota

62. Współdziałanie

63. Współpraca

64. Wykształcenie

65. Zdrowie (choroba)

66. Życie

\section{WSTĘPNA TYPOLOGIA WYODRĘBNIONYCH POJĘĆ}

Po sformułowaniu listy nazw wartości przechodzę do uporządkowania wybranych leksemów. Zacznę od wyjaśnienia podziału na wartości dodatnie i ujemne, którego nietypowa forma została zasygnalizowana wcześniej. W dalszej kolejności omówię dwa typy systematyzacji: podział na pola pojęciowe oraz podział typologiczny (uwzględniający denotację 
nazw) inspirowany systematyką nazw wartości proponowaną przez Jadwigę Puzyninę (Puzynina 1992: 39).

\section{A) PODZIAŁ NA WARTOŚCI DODATNIE I UJEMNE}

Lingwiści zajmujący się problematyką aksjologiczną w proponowanych typologiach wyróżniają wartości pozytywne i negatywne. Branie pod uwagę obu tych kwalifikacji (dodatniej i ujemnej) w opisie wartości jest uzasadnione z perspektywy ogólnej, nieuwikłanej kontekstowo charakterystyki pojęć aksjologicznych. Konstytucja jest jednak dokumentem silnie narzucającym interpretację zawartego w niej słownictwa aksjologicznego. Skonkretyzowane w treści ustawy zasadniczej profile antywartości nie pozwalają na takie uporządkowanie leksemów z uwzględnieniem podziału na wartości pozytywne i negatywne, w którym obie te grupy wartości byłyby traktowane równorzędnie. Prezentowane w Konstytucji antywartości są ujmowane jako zagrożenia dla wartości dodatnich, a więc są niejako podporządkowane pozytywnym. Traktuję je zatem jako pojęcia zależne od odpowiednich kategorii ocenianych in plus. W sformułowanej liście haseł i klasyfikacji polowej antywartości są zapisane w nawiasie okrągłym obok wartości, dla których (w myśl ustawy zasadniczej) stanowią zagrożenie. W tekście Konstytucji antywartości pojawiają się wyłącznie w związku z wartościami chronionymi. Oto wybrane przykłady:

1) praca - bezrobocie

Władze publiczne prowadzą politykę zmierzającą do pełnego, produktywnego zatrudnienia poprzez realizację programów zwalczania bezrobocia (...) (art. 65 ust. 5)

2) równość - dyskryminacja

Wszyscy obywatele są wobec prawa równi (...). Nikt nie może być dyskryminowany (...) z jakiejkolwiek przyczyny.

(art. 32 ust. 1,2)

3) zdrowie - choroba

Każdy ma prawo do ochrony zdrowia (...). Władze publiczne są obowiązane do zwalczania chorób epidemiologicznych i zapobiegania negatywnym dla zdrowia skutkom degradacji środowiska.

(art. 68 ust. 1 i 4 ) 
4) wolność - cenzura

Każdemu zapewnia się wolność wyrażania swoich poglądów oraz pozyskiwania i rozpowszechniania informacji. Cenzura prewencyjna oraz koncesjonowanie prasy są zakazane.

(art. 54, ust. 1,2)

Ponadto negatywnie wartościowane stany rzeczy są w Konstytucji sygnalizowane za pomocą kwalifikatora „zakazane”, przykładowo:

Zakazane jest istnienie partii politycznych i innych organizacji odwołujących się $\mathrm{w}$ swoich programach do totalitarnych metod i praktyk działania nazizmu, faszyzmu i komunizmu (...).

(art. 13)

Posłużenie się kryterium zakazu w przypadku ujemnie ocenianych faktów wskazuje na ich podrzędność wobec stanów wartościowanych pozytywnie. Konstytucyjny zakaz pewnych aktywności obowiązuje wyłączenie ze względu na ochronę stanów rzeczy ocenianych dodatnio (będących przedmiotem uprawnienia lub nakazu).

\section{B) POLA POJĘCIOWE}

Klasyfikacją, która moim zdaniem w najlepszy sposób ujmuje konstytucyjne pojęcia aksjologiczne, jest podział na pola pojęciowe. Pod terminem "pole pojęciowe" rozumiem układ nazw połączonych ze sobą pewnymi relacjami znaczeniowymi, posiadających nadrzędny sem (archisem) łączący znaczenia wszystkich wyrazów mieszczących się w tym samym polu (Szczepankowska 2011: 112). W tak rozumianym polu wyrazowym uwzględnia się układ rzeczowy nazw, czyli naturalne grupowanie się wyrazów w zespoły na podstawie ogólnego, nadrzędnego znaczenia ${ }^{4}$ (Buttler 1967: 42). Ta forma organizacji leksemów pozwala przezwyciężyć ograniczoność typologii treściowych zbyt sztywno ujmujących płynne znaczenia nazw wartości.

Zanim przejdę do prezentacji wyodrębnionych pól pojęciowych i ich zawartości, wspomnę o współistnieniu w Konstytucji alternatywnych systemów aksjologicznych. Według jednego z nich źródłem wartości uniwer-

\footnotetext{
4 Podobnie pole pojęciowe rozumie Ryszard Tokarski, według którego jest to uporząkowana grupa wyrazów powiązanych przynależnościa do wspólnej kategorii znaczeniowej (Tokarski 2001: 362).
} 
salnych jest Bóg. Zgodnie z drugim natomiast wartości te mogą być wywiedzione z „innych źródeł” pochodzących od człowieka. Dualizm źródeł wartości jest jasno określony w Preambule, a jego pojawienie się w tekście ustawy zasadniczej ma wpływ na układ polowy haseł. Oto fragmenty:

(...) my - Naród Polski - wszyscy obywatele Rzeczypospolitej, zarówno wierzący w Boga będącego źródłem prawdy, sprawiedliwości, dobra i piękna, jak i nie podzielający tej wiary, a te uniwersalne wartości wywodzący z innych źródeł (...).

(Preambuła)

W poczuciu odpowiedzialności przed Bogiem lub własnym sumieniem ustanawiamy Konstytucję Rzeczypospolitej Polskiej (...).

(Preambuła)

O współwystępowaniu religijnego i świeckiego systemu wartości świadczy także zawarta w Konstytucji możliwość (nie zakaz lub przymus) wypowiedzenia formuły "tak mi dopomóż Bóg” podczas składania przysięgi przez Prezydenta Rzeczypospolitej (art. 130), Prezesa Rady Ministrów i jego współpracowników (art. 151) oraz przez posłów (art. 104 ust. 2). Tak zarysowany $\mathrm{w}$ ustawie zasadniczej sposób widzenia wartości wymaga sformułowania dwu struktur pojęć aksjologicznych. Układ pól wyrazowych prezentuje się następująco:

\section{Wersja 1}

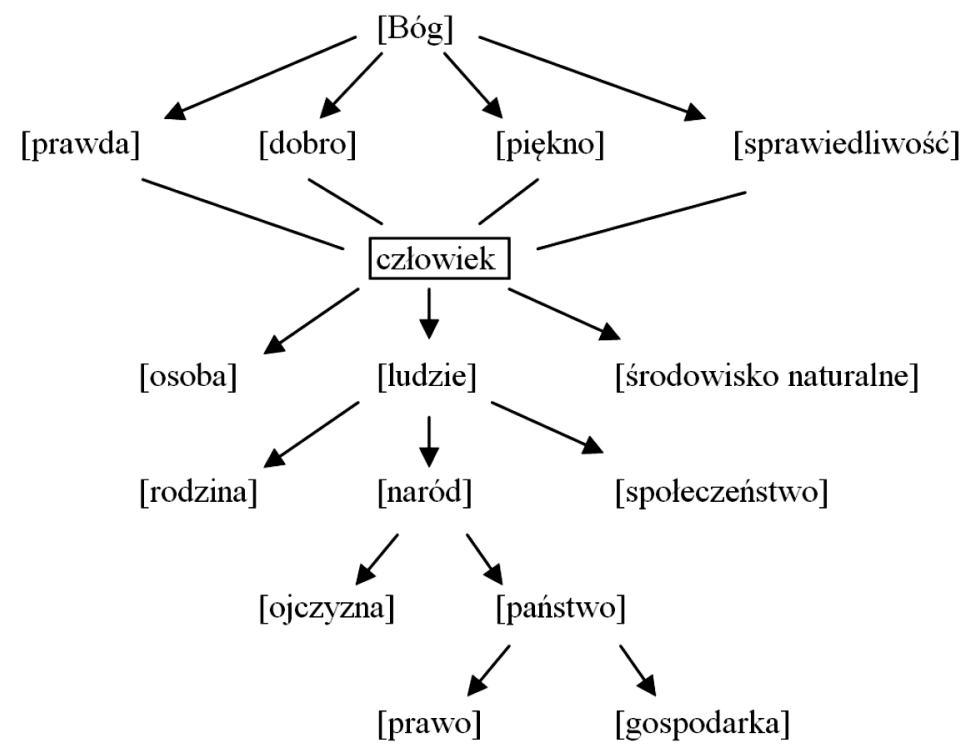




\section{Wersja 2}

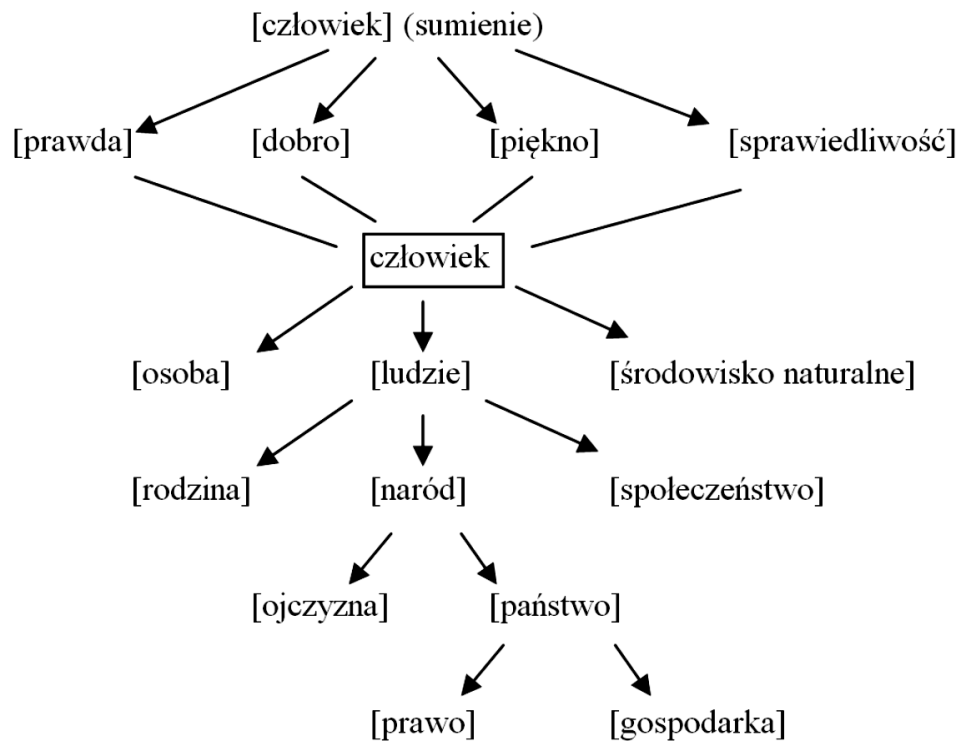

Zaproponowana systematyzacja wymaga komentarza. Nazwy wartości konstytucyjnych zogniskowane są wokół zagadnień społeczno-narodowych oraz państwowo-politycznych. Nadmieniam, iż zaprezentowany podział nie jest wolny od subiektywnie podjętych decyzji klasyfikacyjnych.

W wersji nr 1 na szczycie struktury znajduje się pole pojęciowe [Bóg]. $\mathrm{W}$ alternatywnym układzie polowym najwyższe miejsce $\mathrm{w}$ hierarchii zajmuje kategoria [człowiek]. W obu wersjach układu polowego w dalszej kolejności zostały wymienione wartości uznane w Konstytucji za uniwersalne: [prawda], [dobro], [piękno], [sprawiedliwość]. Poniżej wartości uniwersalnych zostały wskazane obszary, w których takie wartości, jak: prawda, dobro, piękno, sprawiedliwość są urzeczywistniane przez człowieka dla pomyślności i bezpieczeństwa jego samego, wspólnoty narodowej oraz państwa. Jednostka jest tu jednocześnie wartością i „dysponentem", realizatorem wartości wyższych. Pierwszą grupą kategorii, w których przejawiają się wartości uniwersalne, są: [osoba], [ludzie] i [środowisko naturalne]. Pole wyrazowe [osoba] skupia nazwy dóbr uznanych przez jednostkę za wartości ze względu na jej osobistą korzyść. Pole [ludzie] zawiera nazwy grup osób, którym człowiek przypisuje szczególną wartość. Zakres pola leksykalnego [środowisko naturalne] obejmuje nazwy związane ze środowiskiem ekologicznym człowieka, chronionym 
ze względu na bezpieczeństwo jednostki i społeczeństwa. Kolejny poziom reprezentują grupy wyodrębnione z pola pojęciowego [ludzie]: [rodzina], [naród], [społeczeństwo]. Na kategorię [rodzina] składają się nazwy osób spokrewnionych oraz określenia ich wzajemnych relacji. Kategoria [naród] zawiera określenia pewnych obiektów i stanów rzeczy istotnych dla wspólnoty narodowej, stanowiących o jej świadomym istnieniu. W polu wyrazowym [społeczeństwo] znalazły się nazwy ogólnoludzkich postaw i zachowań. Przedostatni szczebel struktury polowej, wyłoniony z kategorii [naród], zajmują pola [ojczyzna] oraz [państwo]. Pole leksykalne [ojczyzna] wypełniają nazwy kojarzące się z miejscem przynależności człowieka i trwaniem wspólnoty ojczyźnianej. Kategorię [państwo] tworzą natomiast nazwy ustrojów politycznych wraz z określeniami obiektów i stanów rzeczy związanych z organizacją polityczną kraju. Ostatnim podziałem jest wyodrębnienie $\mathrm{z}$ pola [państwo] podległych mu mikropól: [prawo] - zawiera nazwy zjawisk związanych z prawodawstwem państwa oraz [gospodarka] - obejmuje określenia dotyczące rzeczywistości ekonomicznej.

Przypisanie nazw wartości konstytucyjnych poszczególnym polom pojęciowym wiąże się z pewnymi trudnościami. Główny problem stanowi systematyzacja tych pojęć, które zgodnie $\mathrm{z}$ ich konstytucyjną interpretacją mają kilka punktów odniesienia lub ich konotacje są odmienne od tradycyjnie przyjętych. Zróżnicowane profile mają takie pojęcia, jak: godność (człowieka/Narodu $5 /$ urzędu), moralność (osoby/publiczna), współdziałanie (władz/państwa/Kościoła), bezpieczeństwo (obywatela/państwa/ekologiczne), równość (równy dostęp do wykształcenia/równość wobec prawa), wolność (zrzeszania się/słowa/głoszenia poglądów). Nietypowa konotacja dotyczy nazw takich zjawisk, jak dia$\log$ (społeczny) i walka (o niepodległość). Tradycyjnie takie wartości, jak godność, moralność, równość, wolność, bezpieczeństwo należałoby wiązać z człowiekiem jako jednostką. Walka i współdziałanie zaś odnoszą się do postaw społecznych, ogólnoludzkich; dialog natomiast przywodzi na myśl osobisty kontakt dwojga interlokutorów. Zgodnie $\mathrm{z}$ rozumieniem tych wartości ujętym w ustawie zasadniczej niektóre profile pojęć można włączyć do innych kategorii, na przykład: godność Narodu - [naród]; godność urzędu, bezpieczeństwo oby-

\footnotetext{
5 Pisownia wielką i małą literą przywołanych nazw wartości jest zgodna z zapisem w Konstytucji.
} 
watela, bezpieczeństwo państwa - [państwo]; moralność publiczna [społeczeństwo]; bezpieczeństwo ekologiczne - [środowisko naturalne]; równość obywateli wobec prawa - [prawo]; wolność zrzeszania się [społeczeństwo].

Wskazanie podziału polowego i próba szczegółowego przyporządkowania wyodrębnionym kategoriom zróżnicowanych profili niektórych konstytucyjnych pojęć aksjologicznych ma prowadzić do sformułowania zasobu leksykalnego pól. Na podstawie charakterystyk nazw wartości ujętych w Konstytucji proponuję następujący układ nazw:

[Bóg]: Bóg, religia, chrześcijaństwo, wiara

[prawda]: prawda, informacja, wykształcenie, nauka

[dobro] ${ }^{6}:$ dobro

[piękno] : piękno

[sprawiedliwość]: sprawiedliwość

[osoba]: dobre imię, godność człowieka, humanitaryzm, moralność, odpowiedzialność, prywatność, równość kobiet i mężczyzn (dyskryminacja), równy dostęp do wykształcenia, szacunek (nienawiść), sumienie, swoboda [wolność] wyrażania przekonań religijnych, światopoglądowych i filozoficznych, wolność wykonywania zawodu, wolność poruszania się po terytorium Rzeczypospolitej, wolność wyboru miejsca zamieszkania, swoboda opuszczania terytorium Rzeczypospolitej, wolność twórczości artystycznej, wolność słowa (cenzura), wolność nauczania, wolność osobista, własność prywatna, zdrowie (choroba), życie

[ludzie]: człowiek, ludzkość, Naród, przodkowie, rodacy

[środowisko naturalne]: bezpieczeństwo ekologiczne, środowisko naturalne

[rodzina]: dziecko, matka, macierzyństwo, małżeństwo, rodzina, rodzicielstwo

[naród]: chrześcijaństwo, dziedzictwo narodowe, godność Narodu, język narodowy, kultura, religia, tradycja, tożsamość narodowa

[społeczeństwo]: dialog społeczny, moralność publiczna, solidarność,

6 Wartość, jaką jest dobro, realizuje się w każdym poddanym aksjologicznej ocenie aspekcie istnienia państwa, społeczeństwa i jednostki. Wszelkie nazwy wartości konstytucyjnych zawierają w swojej konotacji komponent semantyczny 'dobro'.

7 Piękno jest wartością, która nie została w ustawie zasadniczej wyrażona w pojęciu innej wartości (na wzór „dobra”). Pojawia się raczej jako element tradycyjnej triady: prawda, dobro, piękno. 
społeczeństwo, sprawiedliwość społeczna, współpraca, wspólnota, wolność tworzenia związków zawodowych, organizacji społeczno-zawodowych, wolność tworzenia stowarzyszeń, ruchów obywatelskich, zrzeszeń, fundacji, wolność organizowania pokojowych zgromadzeń [ojczyzna]: Ojczyzna, suwerenność

[państwo]: bezpieczeństwo obywateli, bezpieczeństwo państwa, barwy Rzeczypospolitej Polskiej, demokracja (faszyzm, nazizm, komunizm, totalitaryzm, przemoc $^{8}$ ), godło Rzeczypospolitej Polskiej, godność urzędu, hymn Rzeczypospolitej Polskiej, obywatel, pokój (wojna), Polska [Rzeczpospolita], państwo, równość obywateli wobec prawa, niepodległość, terytorium, walka o niepodległość, współdziałanie władz, współdziałanie państwa i kościoła, wolność tworzenia i działania partii politycznych, wolność prasy i mediów [prawo]: Konstytucja, prawo, równouprawnienie, sprawiedliwość, wolność dziedziczenia

[gospodarka]: praca (bezrobocie), gospodarka

\section{C) PODZIAŁ POJĘĆ AKSJOLOGICZNYCH ZE WZGLĘDU NA DENOTACJĘ NAZW}

Podział polowy nie uwzględnia natury wartości ani denotacji ich nazw. Koniecznym uzupełnieniem układu pól pojęciowych jest więc typologia porządkująca nazwy wartości ze względu na zakres ich odniesienia:

I. Źródła wartości: Bóg (wiara) // człowiek (sumienie)

II. Wartości podstawowe:

- uniwersalne: prawda, dobro, piękno, sprawiedliwość

- pozostałe: wolność [swoboda], niepodległość, suwerenność, równość, godność, odpowiedzialność, solidarność, bezpieczeństwo, moralność, tożsamość

III. Wartości instrumentalne: nauka, wykształcenie, informacja, współpraca, współdziałanie, walka, praca, dialog, szacunek, humanitaryzm, równouprawnienie, pokój

IV. Nośniki wartości: osoba [człowiek], ludzkość [ludzie], prywatność [życie prywatne], własność [dobra posiadane], dobre imię [cześć],

\footnotetext{
8 Antywartość „przemoc” pojawia się w Konstytucji w kontekście „zdobywania władzy z użyciem przemocy" (art. 13), kojarzy się zatem z naruszeniem demokratycznych zasad praworządności.
} 
zdrowie, życie, środowisko, obywatel, Naród, rodacy, przodkowie, dziedzictwo narodowe, dziecko, matka, macierzyństwo, małżeństwo, rodzina, rodzicielstwo, wspólnota, społeczeństwo, Bóg, chrześcijaństwo, religia, Ojczyzna, demokracja, państwo, Polska [Rzeczpospolita], terytorium, prawo, Konstytucja, gospodarka, język narodowy, kultura, tradycja

V. Symbole wartości: godło, hymn, barwy Rzeczypospolitej

Pokrótce omówię przyjętą interpretację przywołanych kategorii. Źródła wartości (Bóg lub sumienie człowieka) to kategorie, z których wywodzą się wartości uniwersalne. Wartościami podstawowymi są te, których uznanie przez człowieka dokonuje się z przyczyn niezależnych od subiektywnie pojmowanych korzyści płynących z zachowania tych wartości. Są to inaczej wartości same w sobie, nie traktowane jako środki do zdobywania innych (Puzynina 1992: 31). Wartości instrumentalne zaś stanowiq pośredni etap do zdobywania innych wartości (Puzynina 1992: 31), pełnią więc funkcję pomocniczą, służebną w docieraniu do dóbr podstawowych. Nośnikami (inaczej: nosicielami) wartości są pojęcia określające pewne obiekty, stany rzeczy lub zjawiska, którym człowiek przypisuje szczególne znaczenie. Symbole natomiast to pewne znaki będące reprezentacją określonej aksjologii.

Ze względu na odmienną funkcję pełnioną przez niektóre antywartości w stosunku do wartości dodatnich, którym są przyporządkowane, nie uwzględniłam nazw zagrożeń $w$ omawianej tu typologii. Gdybym brała pod uwagę nazwy wartości negatywnych, musiałabym potraktować je równorzędnie z nazwami dóbr. Takie działanie przeczyłoby wcześniejszej interpretacji antywartości jako podrzędnych względem nazw wartości pozytywnych.

Zrezygnowałam z prezentowania podziału treściowego nazw wartości, ponieważ ten poziom systematyzacji nie jest pomocny na obecnym etapie moich badań słownictwa aksjologicznego. Ponadto przeprowadzenie takiej klasyfikacji nastręcza niemałych trudności, a jej rezultat najczęściej jest dyskusyjny (Puzynina 1992: 33).

\section{PODSUMOWANIE}

Wybór i klasyfikacja konstytucyjnych pojęć aksjologicznych jest pierwszym krokiem w kierunku zbadania semantyki i sposobu rozumie- 
nia nazw wartości. Trudno na tym etapie formułować szczegółowe wnioski badawcze. Charakterystykę wartości istniejących w Konstytucji oraz metodologię klasyfikacji ich nazw podsumuję następująco:

1. W ustawie zasadniczej można znaleźć przynajmniej dwa istniejące obok siebie systemy wartości. Ujawniają się one w Preambule w postaci alternatywnych źródeł wartości uniwersalnych.

2. Aksjologia konstytucyjna wpisuje się $\mathrm{w}$,językowy obraz dobrego państwa" - wartościowanie dotyczy głównie obszaru politycznego (w tym prawnego i gospodarczego) oraz społecznego.

3. Na podstawie kryteriów: semantycznego i pragmatycznego oraz łączliwości składniowej nazw z pewnymi określeniami (typu: bronić, chronić, szanować, zabraniać, zakazywać) wybrano 77 nazw wartości, w tym: 66 nazw wartości dodatnich i 11 nazw kontrwartości.

4. Wartości dodatnie są w centrum aksjologicznym omawianego dokumentu. Antywartości interpretuje się jako zagrożenia dla pożądanych stanów rzeczy, co oznacza, że zostały podporządkowane określonym wartościom pozytywnym. Obie grupy aksjologiczne są więc traktowane nierównorzędnie.

5. W ustawie zasadniczej pewne nazwy wartości są sprofilowane adekwatnie do językowego obrazu świata, którego są częścią. Niektóre określenia wartości mają dodatkowo więcej niż jeden punkt odniesienia (przykładowo godność odsyła do trzech podmiotów, którym ta wartość przysługuje: człowieka, urzędu i narodu). Zróżnicowane ujęcie wartości oraz nietypowe odniesienie ich nazw zostały wzięte pod uwagę $\mathrm{w}$ procesie klasyfikowania pojęć.

6. Zaproponowano dwa typy podziału nazw wartości: system pól semantycznych oraz typologię uwzględniającą denotację nazw.

7. Ze względu na dopuszczalność alternatywnych źródeł wartości sformułowano dwie struktury polowe różniące się uwzględnieniem lub pominięciem kategorii [Bóg] na szczycie klasyfikacji. Pozostałe kategorie w obu systemach pól są identyczne.

8. Uzupełnieniem podziału polowego jest klasyfikacja, w której wzięto pod uwagę denotację nazw. Pozwala ona wyodrębnić: źródła aksjologii, wartości podstawowe i instrumentalne oraz nośniki i symbole wartości.

9. W systematyzacji pominięto uporządkowanie nazw wartości ze względu na ich treść. Na obecnym etapie badań zastosowanie tego rodzaju typologii byłoby pochopne. 
10. Usystematyzowanie nazw wartości ułatwi pracę nad rekonstrukcją ich semantyki, a na dalszym etapie badań umożliwi także sformułowanie pytań ankietowych o sposób rozumienia tych nazw przez przedstawicieli młodego pokolenia Polaków.

\section{BIBLIOGRAFIA}

\section{ŹRÓDŁA}

Konstytucja Rzeczypospolitej Polskiej, 2014, wydanie 15, Warszawa.

\section{LITERATURA}

Bartmiński J., 1991, Projekt i założenia ogólne słownika aksjologicznego, „Język a Kultura", t. 2, Zagadnienia leksykalne i aksjologiczne, red. J. Puzynina, J. Bartmiński, Wrocław, s. 197-209.

Bartmiński J., 2006, Zmiany rozumienia nazw wartości w okresie transformacji ustrojowej w Polsce, [w:] Język - wartość - polityka, red. J. Bartmiński, Lublin, s. 8-35.

Bartmiński J., 2014, Ankieta jako pomocnicze narzędzie rekonstrukcji językowego obrazu świata, [w:] Polskie wartości w europejskiej aksjosferze, red. S. Niebrzegowska-Bartmińska, M. Nowosad-Bakalarczyk, S. Wasiuta, Lublin, s. 309-332.

Bartmiński J., 2014, Kanon aksjologiczny jako narzędzie tożsamości grupowej, [w:] Polskie wartości w europejskiej aksjosferze, red. S. Niebrzegowska-Bartmińska, M. Nowosad-Bakalarczyk, S. Wasiuta, Lublin, s. 10-17.

Buttler D., 1967, Koncepcje pola znaczeniowego, „Przegląd Humanistyczny” nr 2, Warszawa, s. 41-59.

Nietzsche F., 1910, Wola mocy, Warszawa.

Puzynina J., 1992, Język wartości, Warszawa.

Stawrowski Z., 2007, Aksjologia i duch Konstytucji III RP, "Przegląd Sejmowy", nr 4, s. 49-64.

Szczepankowska I., 2011, Semantyka i pragmatyka jezzykowa. Słownik podstawowych pojęć z zadaniami i literatura przedmiotu, Białystok.

Szczepankowska I., 2007, Czym jest pojęcie we wspótczesnym językoznawstwie?, „Białostockie Archiwum Językowe", nr 7, Białystok, s. 170-183.

Tokarski R., 2001, Słownictwo jako interpretacja świata, [w:] Współczesny język polski, red. J. Bartmiński, Lublin, s. 343-370.

Weiler J.H.H., 2003, Chrześcijańska Europa. Konstytucyjny imperializm czy wielokulturowość?, Poznań.

\section{SŁOWNIKI}

Słownik języka polskiego PWN, 2006, red. L. Drabik i in., Warszawa. 


\title{
AXIOLOGICAL LEXIS IN \\ THE CONSTITUTION OF THE REPUBLIC OF POLAND - A SELECTION AND CLASSIFICATION
}

\begin{abstract}
Summary
The article presents a selection and preliminary classification of axiological lexis included in the currently valid Constitution of the Republic of Poland. Typology of names is preceded by the characteristics of the analyzed source and the description of an axiological level of the document. Constitutional axiological terms have been divided into three types. Firstly, a division into positive and negative values has been introduced. It has been noticed that a manner of presentation of counter values in the Constitution indicates inequality of negative values in relation to positive values. Secondly, the names have been grouped into lexical fields and two field structures being a reflection of the constitutional dualism of the sources' values have been formulated. Thirdly, a division of the terms including denotation of names has been made and the following has been distinguished: a source of values, basic and instrumental values as well as their carriers and symbols. A detailed indication of the names and types of values protected in the Constitution leads to the revelation of the set of values professed by the civil community. A typological study of the gathered lexical material evokes methodological difficulties but still creates a necessary basis of a more profound semantic analysis.
\end{abstract}

Key words: names of values, classification of names, constitutional values, axiological terms 